\title{
Isosexual precocious puberty with primary hypothyroidism: an interesting case report
}

\section{Kaliki Hymavathi*, Surekha Tadisetti, Divya Pusarla, Malini Devi Gottipati}

Department of Obstetrics and Gynecology, NMCH, Nellore, Andhra Pradesh, India

Received: 23 June 2017

Accepted: 19 July 2017

\section{*Correspondence:}

Dr. Kaliki Hymavathi,

E-mail: drhymakrreddy@yahoo.co.in

Copyright: () the author(s), publisher and licensee Medip Academy. This is an open-access article distributed under the terms of the Creative Commons Attribution Non-Commercial License, which permits unrestricted non-commercial use, distribution, and reproduction in any medium, provided the original work is properly cited.

\begin{abstract}
Isosexual precocious puberty in a girl child is defined as thelarche before 6 years in African-Americans and 7 years in Caucasians and menarche before the age of 9 years. In 1960, Van Wyk and Grumbach first described a syndrome characterised by breast development, uterine bleeding and multicystic ovaries in the presence of long standing primary hypothyroidism. We describe an interesting case of 8 year old girl presented with the complaint of abdominal mass with history of premature menarche and breast development. She is found to have gross hypothyroidism, hyperprolactinemia, prepubertal LH levels, multicystic ovaries and delayed bone age. Thyroid replacement amazingly settled her problems bringing her to normalcy.
\end{abstract}

Keywords: Abdominal mass, Hypothyroidism, Precocious puberty

\section{INTRODUCTION}

Van Wyk Grumbach syndrome is characterized by juvenile hypothyroidism, delayed bone age and isosexual precocious puberty with reversal to pre pubertal state following Thyroxine replacement therapy. ${ }^{1}$

The etiology of precocious puberty varies from idiopathic cases to those with an underlying serious illness. Different management protocols will be required. ${ }^{2}$ By putting primary hypothyroidism in mind, unnecessary surgeries (grossly enlarged cystic ovaries) can be avoided and simple treatment can solve the entire problem.

\section{CASE REPORT}

An 8 year old girl studying $2^{\text {nd }}$ class was brought by her mother to the Gynaecology outpatient department of Narayana Medical College and Hospital (NMCH), a tertiary care centre, Nellore, Andhra Pradesh, India with c/o cyclical bleeding per vagina since 2 years, scanty in amount, lasts for 3-5 days every 30days. H/o cold intolerance with occasional constipation for last 1-2 years.

She was born of non-consanguineous marriage as full term normal vaginal delivery, is second in her birth order, her elder sibling attained menarche at $12 \mathrm{yrs}$ of age.

\section{On examination}

Height $-106 \mathrm{~cm}$, weight $-24 \mathrm{~kg}$, BMI $-17.04 \mathrm{~kg} / \mathrm{m}^{2}$, Pulse $-68 / \mathrm{min}, \mathrm{BP}-96 / 60 \mathrm{~mm}$ of $\mathrm{Hg}$, Anaemia (+), skin is cold, dry and scaly. Facial puffiness (+), Thyroid enlargement (+). Breast examination - Tanner's stage 2, Axillary hair - absent. P/A: Truncal obesity (+) and a cystic nontender mass of about 18-20 weeks pregnant uterus size is felt in the hypogastrium with restricted mobility. Local exam - Pubic hair absent, external genitalia appears normal. Per vag exam not attempted. Per rectal exam she was not co-operative. 


\section{Investigations $\mathrm{Hb}$}

$9 \mathrm{~g} / \mathrm{dl}$ and all other routine investigations were within normal limits (WNL).

Special investigations are in Table 1.

Table 1: Special investigations.

\begin{tabular}{|lll|}
\hline Investigations & Result & Normal range \\
\hline $\begin{array}{l}\text { Free triiodothyronine } \\
\text { (FT3) }\end{array}$ & $\downarrow 1.40 \mathrm{pg} / \mathrm{ml}$ & $2.50-3.90 \mathrm{pg} / \mathrm{ml}$ \\
\hline $\begin{array}{l}\text { Free } \\
\text { thyroxine (FT4) }\end{array}$ & $\downarrow 0.17 \mathrm{ng} / \mathrm{ml}$ & $0.61-1.12 \mathrm{ng} / \mathrm{ml}$ \\
\hline $\begin{array}{l}\text { Thyroid } \\
\text { stimulating } \\
\text { hormone (TSH) }\end{array}$ & $\uparrow \uparrow>100 \mathrm{miu} / \mathrm{l}$ & $0.34-5.60 \mathrm{miu} / 1$ \\
\hline $\begin{array}{l}\text { Serum follicle } \\
\text { stimulating hormone } \\
\text { (Sr. FSH) }\end{array}$ & $5.04 \mathrm{miu} / 1$ & $3.0-13.0 \mathrm{miu} / 1$ \\
\hline $\begin{array}{l}\text { Serum luteinizing } \\
\text { hormone( LH) }\end{array}$ & $\downarrow \downarrow 0.06 \mathrm{miu} / 1$ & $0.5-10.5 \mathrm{miu} / \mathrm{l}$ \\
\hline $\begin{array}{l}\text { Serum prolactin } \\
\text { (Sr.Pr) }\end{array}$ & $\uparrow 33.5 \mathrm{ng} / \mathrm{ml}$ & $1.20-19.50 \mathrm{ng} / \mathrm{ml}$ \\
\hline Serum estradiol (E2) & $30.5 \mathrm{pg} / \mathrm{ml}$ & $<10 \mathrm{pg} / \mathrm{ml}$ \\
\hline
\end{tabular}

Trans abdominal Ultrasonogram (Figure 1) showed bulky uterus $-7.8 \times 3.5 \times 4.5 \mathrm{cms}$. Utero cervical ratio is greater than 1. Both right and left Ovaries were markedly enlarged with multiple cysts.

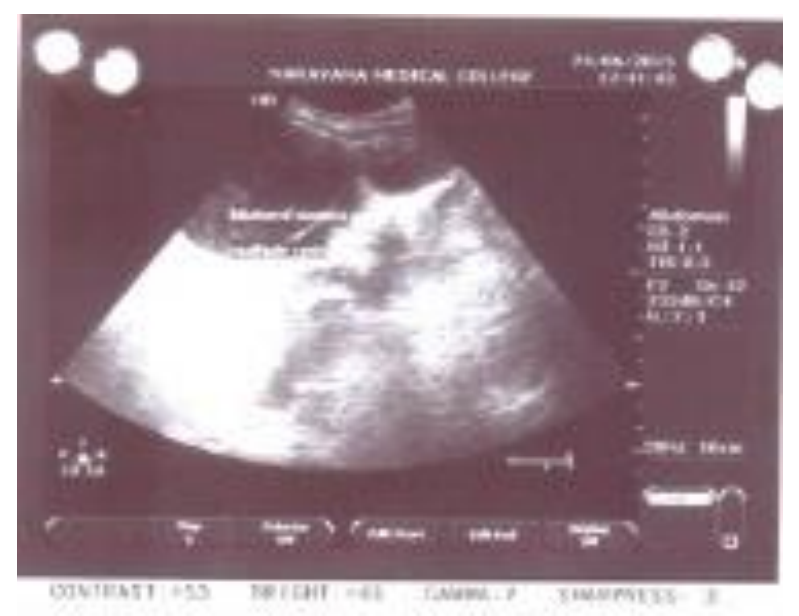

Figure 1: Ultrasoound abdomen.

Endocrinology referral was done in view of altered Thyroid profile and elevated Prolactin levels- advised XRay both forearms for chronological bone age which showed approximate bone age of 3-5yrs indicating delayed bone age (below chronological age).

Management: diet-1585K.cal (Protein 47gms)/day; Tab Thyroxine $50 \mu \mathrm{g}$ daily for 2 weeks. The results of treatment with Thyroxine replacement were found to be amazing clinically evidenced by rapid regression in the size of abdominal mass. Patient discharged with review after 3 months continuing the same treatment.

\section{Review after 3 months}

No menstruation in the last two months. P/A: Soft with no palpable masses. USG: WNL, Thyroid profile: WNL. She was advised to take Tab. Eltroxin $25 \mu \mathrm{g}$ on alternate days and for review after 6 months.

\section{DISCUSSION}

The term precocious puberty is reserved for girls who exhibit any secondary sex characteristics before the age of 8 or menstruation before the age of 10 . Precocious puberty may be isosexual where the features are due to excess Estrogen production or heterosexual where features are due to excess production of Androgens (ovarian and adrenal).

Precocious puberty is generally classified as gonadotropin dependent, gonadotropin independent or combination of the two. Hypothyroidism is an uncommon gonadotropin dependent cause of precocious puberty. ${ }^{3}$ The association between early pubertal development and primary hypothyroidism was first described over 40 years ago and with many reports since then But there are no reports on the frequency of this condition. In 1960 Van Wyk and Grumbach first described a syndrome characterised by breast development uterine bleeding and multi cystic ovaries in the presence of longstanding primary hypothyroidism. ${ }^{4}$ Phenotypically girls show the classical hypothyroid appearance, FSH related secondary sexual characteristics with breast development, periodic uterine bleeding and absence of pubic/axillary hair development. Imaging studies typically reveal enlarged multicystic ovaries with follicular development and a pubertal uterus. Unique to this condition is a delayed bone age. All these features are found to be existing in our patient also.

\section{Pathogenesis:}

The pathophysiology of the VWGS involves a complex interaction between different hypothalamic-pituitary hormonal axes. In the original description, Vanwyk and Grumbach hypothesised that there was hormonal overlap in the pituitary feedback mechanism. This overlap was thought to be partly at the hormone molecular level, given that both TSH and gonadotropins are glycoproteins, and/or partly due to a lack of specificity at the hypothalamic level. ${ }^{5}$ TRH-induced TSH excess may be the common stimulator of the FSH receptor. The fascinating aspect of this syndrome is that TRH-induced hyperprolactinemia likely suppresses the pituitary gonadotropin axis.

Several theories have been proposed to explain precocious puberty caused by hypothyroidism. Van Wyk and Grumbach suggested increased pituitary production 
of not only TSH but also FSH, LH and Prolactin when there was no negative feedback from Thyroid hormone. The current and most widely accepted theory is that high levels of TSH act on FSH receptors because of the molecular similarities between the two hormones. TSH acts as gonadotropin in the ovaries or testes. Stimulation of the gonadal FSH receptor by TSH is supported by the specific FSH/Estrogen dominant clinical picture and histopathology findings. Girls with this syndrome have breast development, follicular cysts and menstruation in the absence of pubic or axillary hair, which depends on adrenal androgens. ${ }^{4,6}$

Histopathological analyses of resected ovaries and ovarian cysts shows cystic follicles and little if any luteinisation. The prepubertal phase, where low FSH levels prevail, could be vulnerable to FSH receptor stimulation by TSH. ${ }^{6,7}$ A dose-dependent response of the FSH receptor to TSH is assumed as only very few children, all with extremely high TSH levels, are affected. This hypothesis is well supported by in vitro experiments. $^{7}$ The glycoprotein TSH, FSH, LH and hCG share a common $\alpha$ - subunit but have a unique $\beta$-subunit that is specific to each hormone. They each act through transmembrane G-protein coupled receptors (GPCRs) to activate adenylate cyclase and stimulate cAMP production. ${ }^{7}$ Anasti et al showed that recombinant human TSH elicited a dose-dependent response at the human FSH receptor.

The TSH concentration required was several orders of magnitude higher than FSH, demonstrating that the FSHlike activity of TSH is very low. They went on to show that TSH and FSH are acting through the same receptor and that TSH competitively antagonises FSH. Whether a mutation or allelic variation in affected individuals leaves them more susceptible to TSH acting through the FSH receptor, Ryan et al. ${ }^{7}$ sequenced the human $\mathrm{FSH}$ receptor gene in eight patients with gonadal hyper stimulation secondary to primary hypothyroidism. They found no mutations and no variance in the sensitivities of different allelic combinations or polymorphisms of the human FSH receptor. They confirmed previous study results that a very high concentration of TSH can directly cause activation of the wild-type FSH receptor. ${ }^{5}$ One may speculate that TSH could also be acting through its own receptor on the ovary, but this is considered less likely as hypothyroidism more commonly presents with ovarian insufficiency and delayed puberty. ${ }^{8}$

\section{Abdominal mass}

Girls with acquired primary hypothyroidism may also present with abdominopelvic masses - large ovarian cysts caused by hyper stimulation. In present case, also major complaint was mass in the abdomen (18-20 weeks of pregnant uterus size). Along with premature menarche stimulation of the gonadal FSH receptor by elevated TSH is supported by the specific FSH/Estrogen dominant clinical picture and histopathology findings.
The role of Prolactin has long been argued in this syndrome, especially as Prolactin has not been elevated in every reported case. ${ }^{9}$ Loss of negative feedback from Thyroid hormones in primary hypothyroidism not only results in high TRH levels, hyperplasia of the TSH secreting cells in the pituitary but also stimulates Prolactin secretion. In addition, elevated Estrogen concentrations reduce Prolactin inhibitory factor via a negative feedback mechanism, causing a further increase in Prolactin. ${ }^{10}$ Prolactin is known to suppress pituitary gonadotropin by slowing GnRH pulse frequency. ${ }^{11}$ Slow GnRH pulses preferentially lead to suppression of LH and production of FSH. ${ }^{12}$ Prolactin also sensitises the ovary to circulating gonadotropin and accelerates follicular maturation via a poorly understood mechanism Bromocriptine given to rats with hCG-induced sexual precocity inhibits ovarian cyst formation.

The presence of precocious puberty and enlarged ovaries suggested an Estrogen secreting ovarian tumour in the present case. But the finding of a delayed bone age in the patient with precocious puberty narrowed the differential diagnosis to long standing hypothyroidism. High circulating levels of TSH along with prepubertal LH levels suggested VWGS. On imaging the abdominal mass was found to be the grossly enlarged ovaries. The sequence of events that results in ovarian hyper stimulation is unclear. This may simply be the consequence of increased TSH levels interacting and stimulating gonadotropin release. It is of note that FSH levels are not particularly high in long standing primary hypothyroidism despite the degree of gonadal stimulation.

\section{Delayed bone age}

Precocious puberty usually present with accelerated growth velocity and advanced bone age. However precocious puberty may not be associated with increased growth velocity if there is concurrent growth hormone deficiency in conditions such as post radiation, post meningitis and encephalitis or if there is thyroid hormone deficiency due to hypothyroidism which results in insulin-like growth factor (IGF-1) generation and chondrocyte differentiation.

Although our patient height was below the $3^{\text {rd }}$ centile, her predicted adult height was within 1 SD of her target height which suggested that her growth was not compromised considerably despite her hypothyroidism. This possibly could be due to recent onset of hypothyroidism as patients with congenital hypothyroidism usually have more retarded growth and bone age corresponded with chronological age. Underlying hypothyroidism should be considered when precocious puberty is associated with deceleration in linear growth. Unfortunately, growth was not measured in this child from age 18 months until her arrival at six years of age. 


\section{Anaemia}

Anaemia is not so uncommon in hypothyroidism and has been noted in several case reports of the VWGS. ${ }^{6,10}$ The proposed mechanism involves decreased red cell production in response to the reduced metabolic requirements for oxygen in tissues due to hypothyroidism. In addition, the anaemia may also be exaggerated by menorrhagia, dietary deficiency or pernicious anaemia as part of an autoimmune 'cluster'.

\section{CONCLUSION}

The unique elements that lead to this diagnosis are FSHdominated sexual precocity combined with a delayed bone age in the presence of hypothyroidism. It is important to recognise this syndrome early because initiating simple Thyroid hormone replacement completely resolves symptoms and hormone abnormalities. Non-recognition can lead not only to a delay in diagnosis but also to unnecessary surgical procedures. Surgery should only be indicated if there is ovarian torsion or if the cystic enlargement does not regress with treatment. ${ }^{7,13}$

Funding: No funding sources

Conflict of interest: None declared

Ethical approval: Not required

\section{REFERENCES}

1. Styne DM, Grumbach MM. William's textbook of Endocrinology. $11^{\text {th }}$ ed. Saunders Puberty. Ontogeny, neuroendocrinology, physiology and disorders. Elsevier. Philadelphia;2008:969-1166.

2. Taher BM, Ajlouni HK, Hamamy HA Shegem NS, Madanat AY, Ajlouni KM. Precocious puberty at an endocrine centre in Jordan. Eur $\mathbf{J}$ Clin Invest. 2004;34:599-604.

3. Wormsbecker A, Clarson C. Acquired primary hypothyroidism: vaginal bleeding in a quiet child. CMAG. 2010;182:588-590.

4. Bassam T, Ajlouni K. A case of ovarian enlargement in severe primary hypothyroidism and review of the literature. Ann Saudi Med. 2006;26(1):66-8.

5. DeLeener A, Montanelli L, VanDurme J, Chae H, Smits G, Vassart G, Costagliola S. Presence and absence of follicle stimulating hormone receptor mutations provide some insights into spontaneous ovarian hyper stimulation syndrome pathophysiology. J Clin Endocrinol Metab. 2006;91:555-62.

6. Shu J, Xing L, Zhang L, Fang S, Huang H. Ignored adult primary hypothyroidism presenting chiefly with persistent ovarian cysts: a need for increased awareness. Reprod Biol Endocrinol. 2011;9:119.

7. Ryan GL, Feng X, d'Alva CB, Zhang M, VanVoorhis BJ, Pinto EM et al. Evaluating the roles of follicle-stimulating hormone receptor polymorphisms in gonadal hyperstimulation associated with severe juvenile primary hypothyroidism. J Clin Endocrinol Metab. 2007;92:2312-7.

8. Durbin KL, Diaz-Montes T, Loveless MB. Van Wyk and Grumbach syndrome: an unusual case and review of the literature. J Pediatr Adolescent Gynaecol. 2011;24:93-96.

9. Sharma Y, Bajpai A, Mittal S, Kabra M, Menon PSN. Ovarian cysts in young girls with hypothyroidism: follow up and effect of treatment. J Pediatr Endocrinol Metab. 2006;19:895-900.

10. Hunold A, Alzen G, Wudy SA, BluettersSawatzki R, Landmann E Reiter A et al. Ovarian tumour in a 12year old female with severe hypothyroidism: a case of Van Wyk and Grumbach syndrome. Pediatr Blood Cancer. 2009;52:677-9.

11. Krassas GE, Poppe K, Glinoer D. Thyroid function and human reproductive health. Endocrine Rev. 2010;31:702-755.

12. Thackray VG, Mellon PL, Coss D. Hormones in synergy: regulation of the pituitary gonadotropin genes. Molecular Cellular Endocrinol. 2010;314:192203.

13. Kroeze WK, Sheffler DJ, Roth BL. G-proteincoupled receptors at a glance. J Cell Sci. 2003;116:4867-9.

Cite this article as: Hymavathi $\mathrm{K}$, Tadisetti S, Pusarla D, Gottipati MD. Isosexual precocious puberty with primary hypothyroidism: an interesting case report. Int J Reprod Contracept Obstet Gynecol 2017;6 4140-3. 